\title{
Functional Properties and Preparation of Diet Apricot Jam
}

Tariq Kamal $^{1 *}$, Sana Khan ${ }^{2}$, Muhammad Riaz ${ }^{3}$ and Mehnaz Safdar ${ }^{1}$

${ }^{1}$ Department of Agricultural Extension Education and Communication, Faculty of Rural Social sciences, The University of Agriculture Peshawar, Pakistan

${ }^{2}$ Department of Food Science and Technology, The University of Agriculture, Peshawar, Pakistan

${ }^{3}$ Department of Crop Breeding and Genetics Faculty of Crop Production, The University of Agriculture, Peshawar, Pakistan

\begin{abstract}
This research was conducted to prepare apricot diet jam from the pulp of fresh mature apricots by using artificial sweeteners i.e. aspartame and saccharine. Apricots were washed with clean water to remove dust particles. After sorting and pitting, apricots were cut into two halves with the help of stainless steel knives and dipped in $0.1 \%$ citric acid solution to avoid browning. The pulp of apricots was extracted by using plumper. Apricot pulp was heated to get the desired consistency. Low heating was continued and brix were noted after every 20 minutes. At the end two different artificial sweeteners were used for the preparation of jam. Pectin with small amount of non nutritive sweeteners were dissolved separately and added to the mixture. Preservatives and color was added at the end of cooking. At $21^{\circ}$ brix the product was poured into the jam bottles, already washed, cleaned, sterilized and without moisture. Bottles were caped and stored at ambient room temperature. After three days the samples were studied for their chemical characteristics. The parameter (i.e.) moisture, acidity, total soluble solids, ascorbic acid, $\mathrm{pH}$, reducing sugar and non reducing sugar were determined in apricot diet jam. Physicochemically the mean values of the results were $3.69 \mathrm{pH}, 0.66 \%$ total acidity, $6.54 \%$ vit. C (mg/100 g), $77.01 \%$ moisture, $21.3 \%$ TSS, $4.13 \%$ reducing sugars, and $9.2 \%$ non reducing sugars.
\end{abstract}

Keywords: Preparation apricot diet jam; Preservatives; Chemical characteristics

\section{Introduction}

The total area under cultivation in Pakistan was 31256 hectares with the total production of 240192 tones. The total area under cultivation in NWFP was 2313 hectares with the total production of 19680 tones. The total area under cultivation in Punjab was 42 hectares with the total production of 236 tones. The total area under cultivation in Balochistan was 28901 hectares with the total production of 220276 tones [1].

The apricot "Prunus armeniaca" is a member of the rosaece family, along with peaches, plum, cherries and almonds. The word apricot comes from the Latin Praecocia meaning "early ripening" or "Precocious". It is generally assumed that this important specie of fruit comes from Turkistan, where it grows in the wild up to an altitude of 2,000 meters. It is cultivated in China since 3,000 B.C. The apricot tree spread in Europe (first Italy, then Greece) at the beginning of the Christian era. It is introduced by the Romans after their conquest of Armenia. In the tenth century, it was introduced by Arabs to Southern France, while in America it did not arrive until after 1700 Wills [2].

The chemical composition of the seed shell of the apricot (Prunus ameniaca). Acid and neutral detergent fibers (ADF and NDF) and their fractions hemicellulose, cellulose and lignin were determined. The NDF content was about $920 \mathrm{~g} \mathrm{~kg}^{-1} \mathrm{DM}$. the concentrations of oils, soluble, sugar pectins, polyphenolic compounds, proteins and mineral elements were also determined. None of these fractions was present at levels higher than $25 \mathrm{~g} \mathrm{~kg}^{-1} \mathrm{DM}$. Essential amino acids comprised 38$41 \%$ total amino acids. Potassium $\left(2.44 \mathrm{~g} \mathrm{~kg}^{-1}\right)$ was the most abundant element, followed by calcium $\left(1.15 \mathrm{~g} \mathrm{~kg}^{-1}\right)$ Canellas [3].

Artificial sweeteners or sugar substitutes are organic materials used to sweeten food. The nutritive additives includes (white sugar, honey, corn syrup, brown sugar and fructose) all these are responsible for increasing the blood glucose level, while non-nutritive sweetness are industrially processed including saccharine, aspartame, sucralose, and acesulphame K. Saccharine, aspartame, sucralose, and ace-suphame K approved by the FDA and these can be used in safe limits FDA [4].
Non nutritive sweeteners are used in many foods in place of caloric sweeteners. The nutritive sweeteners are responsible for causing many diseases (e.g. obesity, cardiovascular problem, diabetes, dental carries, and behavioral disorder). So in order to overcome these community food problems food industry has responded to this demand and producing a number of non caloric sweeteners Anderson [5].

Food formulated for diabetics or weight reduction tends to replace bulk caloric sweeteners with high intensity sweeteners. Reduced calorie foods were an important area for product development. Foods formulated for diabetics and/or weight reduction tends to replace bulk calorie sweeteners with high intensity sweeteners. A mixture of experimental design was used to model the acceptability of low calorie dessert mix sweetened with single, binary and tertiary combination of saccharin, cyclamate and stevioside. The design included constraints to permit sweetener addition according to the limits of food laws. The dessert mixture had a $37 \%$ calorie reduction when compared to the sucrose sweetened pudding, and texture equivalent to commercial products was reproduced with the addition of $0.01 \mathrm{~g} / 100 \mathrm{ml}$ carrageenan. The most acceptable combination of the sweeteners tasted was saccharin: cyclamate (0.755: 0.245$)$, but other sweeteners could be used to obtain an acceptable product taking cost of the ingredients into consideration Lop [6].

More than 170 million Americans consumed low-calorie foods and beverages. The interest of the consumer in low-calorie foods that contained alternative sweeteners had grown. Currently non-nutritive

${ }^{*}$ Corresonding author: Kamal T, Department of Agricultural Extension Education and Communication, Faculty of Rural Social sciences, The University of Agriculture Peshawar, Pakistan, E-mail: tariqkamal10@gmail.com

Received May 23, 2015; Accepted June 15, 2015; Published June 22, 2015

Citation: Kamal T, Khan S, Riaz M, Safdar M (2015) VFunctional Properties and Preparation of Diet Apricot Jam. J Food Process Technol 6: 475. doi:10.4172/21577110.1000475

Copyright: $\odot 2015 \mathrm{Kamal}$ T, et al. This is an open-access article distributed under the terms of the Creative Commons Attribution License, which permits unrestricted use, distribution, and reproduction in any medium, provided the original author and source are credited. 
high intensity sweeteners, aspartame and sucralose had been approved for use in the United States. Another sweetener, alitame, used in other countries such as Australia and China had not been granted approval for use in the States. The paper reviewed the stability and degradation products of high-intensity sweeteners, aspartame, alitame and sucralose Hutchinson [7].

Mohammad [8] studied the effect of sulphiting and drying methods on physico-chemical and sensorial quality of dried apricots during ambient storage. They pre-treated fresh mature and ripe apricots after preparations with potassium meta-bisulphite (KMS) at concentrations of 2-8\% for 30, 45 and 60 min followed by drying in solar tunnel dryer and in open air. After completion of drying, they packed the samples in polyethylene pouches and evaluated for various quality parameters at 0,6 and 12 months of ambient storage. KMS pre-treatment at concentration of $6 \%$ for 60 min prior to drying helped significantly in improving and maintaining the quality of dried apricots for up to 12 months of ambient storage. Solar tunnel drying resulted in hygienic product and reduced the drying time to 3-4 days compared with 14 -16 days in open air drying. Residual free sulphur dioxide of apricots pre-treated at KMS concentration of $6 \%$ for $60 \mathrm{~min}$ was within the prescribed limits of the Fruit Product Order (1955) specifications for dried products.

Zhu [9] stated that sodium cyclamate is currently available in more than 90 countries worldwide, including several European countries and China, and is being used in products such as tabletop sweetener, food, beverage, confectionary and pharmaceutical industries. In most countries, which are using sodium cyclamate, the acceptable daily intake (ADI) value is $0-11 \mathrm{mg} / \mathrm{kg}$ body weight.

Henkel and Reitz [10] reported that aspartame is synthesized from two amino acid, the building blocks of life, aspartic acid and the methyl ester of phenylalanine. When absorbed by humans, approximately $1 / 10$ of the aspartame dose is converted to methanol. The conversion to methanol takes place when ingested aspartame encounters the enzyme chymotrypsin in the small intestine. After this conversion, methanol is converted to formaldehyde, followed by format. The format is then converted in to carbon dioxide and water. These conversions are all naturally occurring metabolic process in the human body.

Mailk [11] reported that three intense sweeteners, aspartame, acesulfame- $K$ and sucralose, were incorporated singly in lime - lemon flavored carbonated beverage in optimized concentrations on a sucrose equivalence basis at controlled $\mathrm{pH}$ conditions. The beverages were stored for 60 days at 4,27 and $37^{\circ} \mathrm{C}$ and the sweetener concentration determined by HPLC. The loss of aspartame was maximum (29.5\%) while that of sucralose was minimum (1.9\%) at the end of 60 days storage at $37^{\circ} \mathrm{C}$. In the case of acesulfame-k the loss was $6.1 \%$. Sucralose was more stable than the other sweeteners.

Machado [12] investigated the presence of European stone fruit yellows (ESFY or $16 \mathrm{SrX}-\mathrm{B}$ ) phytoplasmas in apricots in Austria. They studied a severe decline of apricot trees, present in Austria for several years, had reached notifiable levels. Initial symptoms on affected trees resembled deficiencies in water and nutrient supplies, expressed as leaf rolling, chlorosis and early reddening, that was leading to sudden dieback during the growing season. Small, wilted fruit and dried leaves might also persist during the autumn. Phytoplasmas belonging to the 16 SrX-B subgroup of European stone fruit yellows (ESFY) were identified by nested polymerase chain reaction/restriction fragment length polymorphism analysis in a high percentage of affected trees from two different regions of Austria.

Awan and Rehman [13] described a fruit jam preparation procedure. Pectin Grade 150 Rapid set was recommended at the rate of $5 \mathrm{~g}$ per $2 \mathrm{Kg}$ of finished material. Sodium Benzoate at the rate of $0.1 \%$ was used like a preservative.

Alizai [14] while studying the economics of drying apricots and their product in Swat, Peshawar and Northern Areas of Pakistan and Afghanistan reported that treating apricot products with PPO (Polyphenoloxidase) inhibitors and their chilating agents prior to dehydration was found to be more effective than using sulfite alone in view of their physical properties (color, texture) and shelf-life. These formulations do not usually provide extent of protection obtained with sulfite.

The objective of this research work is to reduce post harvest losses of apricot and to prepare a diet jam for obese people, diabetic patients and for those who are prohibited to use nutritive sweeteners on health problems.

\section{Materials and Methods}

Fresh mature apricots were purchased from Peshawar fruit market and were transported in wooden crates to the food science section of the PCSIR, Laboratories Complex Peshawar, where the research work was carried out.

\section{Pre blanching operation}

Apricots were washed with clean water to remove dust and extraneous material. Then after pitting apricots were cut into two haves and were submerged in $1 \%$ citric acid solution.

\section{Blanching}

Pitted apricot halves were blanched in citric acid solution (0.1\%) for two minutes at $212^{\circ} \mathrm{F}$ to avoid possible enzymatic reactions.

\section{Pulp extraction}

Fruit pulp was extracted with the help of grinder/juicer by adding the apricot pieces in pulp extracting machine.

\section{Preparation of jam}

Different ratios of sweeteners non caloric were taken and used for jam preparation according to the formula and procedure of Awan and Rehman [13]. The jam samples were cooked in the open steel container. The fruit pulp were taken in an open container for each treatment and heated. At the same time commercial grade pectin with small amount of non caloric sweeteners were dissolved separately and added to the mixture in container. Preservatives and color was added at the end of cooking.

\section{Chemical Analysis}

\section{pH}

$\mathrm{pH}$ of the sample was measured by INOLAB DIGITAL $\mathrm{pH}$ meter according to manual instruction of the apparatus the specification of the apparatus is bench top model level 1 made of Germany.

\section{Procedure}

Turn on the $\mathrm{pH}$ meter and standardized $\mathrm{pH}$ meter by using $\mathrm{pH} 4$ and 7 buffer solutions. Then used deionized distilled water to wash the electrodes and dried with tissue paper before measuring the $\mathrm{pH}$ of the sample. 


\section{Total soluble solids}

The total soluble solids were determined by standard method of AOAC using Abbe refractometer at room temperature.

\section{Procedure}

Before operating the temperature of the equipment was adjusted according to room temperature placed the samples between the two lower prisms and then rotating the connecting arm until the critical ray centered in the eyepiece, reading was taken directly in ${ }^{\circ}$ brix.

\section{Titratable acidity}

Titratable acidity was determined in duplicate by standard method of AOAC.

\section{Standardization of $0.1 \mathrm{~N} \mathrm{NaOH}$ solutions}

$6.3 \mathrm{~g}$ of oxalic acid were accurately weighed, dissolved in distilled water and the volume was made to $1000 \mathrm{ml}$. The burette was then filled with roughly prepared $0.1 \mathrm{~N} \mathrm{NaOH}$ solution and $10 \mathrm{ml}$ to $0.1 \mathrm{~N}$ oxalic acid solution were taken in a beaker. One to two drops of phenolphthalein as indicator were added to the beaker. The $\mathrm{NaOH}$ was treated against oxalic acid until high pink color appeared. Three consecutive readings were taken and the normality of $\mathrm{NaOH}$ was calculated using the formula.

$\mathrm{N}_{1} \mathrm{~V}_{1}=\mathrm{N}_{2} \mathrm{~V}_{2}$

Where

$\mathrm{N}_{1}=$ Normality of $\mathrm{NaOH}$ solution

$\mathrm{V}_{1}=$ Volume of $\mathrm{NaOH}$ solution

$\mathrm{N}_{2}=$ Normality of oxalic acid solution

$\mathrm{V}_{2}=$ Volume of oxalic acid

After this accurate $0.1 \mathrm{~N} \mathrm{NaOH}$ was prepared by adding the required distilled water.

\section{Titration of Samples}

$10 \mathrm{ml}$ of diluted sample was taken in a small flask and added two drops of phenolphthalein as indicator; titration was carried out against $0.1 \mathrm{~N} \mathrm{NaOH}$ solution until light pink color appeared. Three consecutive readings were taken and acidity was calculated by using the following formula.

$$
\% \text { Acidity }=\underline{\mathrm{T} \times 0.1 \mathrm{~N} \times 0.067 \times 100 \times 100}
$$

$$
\mathrm{L} \times \mathrm{M}
$$

$\mathrm{T}=\mathrm{m} 1$ of $\mathrm{NaOH}$ used

$\mathrm{L}=$ sample taken in $\mathrm{g}$ for dilution

$\mathrm{M}=\mathrm{m} 1$ of diluted sample taken for titration

Moisture content: Moisture content of the jam samples was determined in duplicate by modification of the vacuum oven method AOAC [15].

Moisture $(\%)=\underline{\text { Difference in weight } \times 100}$

$$
\text { Weight of sample }
$$

Ascorbic acid: Ascorbic acid was determined by the titration method as reported in AOAC [15].

\section{Preparation of dye solution}

2, 6 Dichlorophenol indophenol dye $50 \mathrm{mg}$ and $42 \mathrm{mg}$ sodium bicarbonate $\left(\mathrm{NaHCO}_{3}\right)$ were taken in the beaker and then dissolved in distilled water. The volume was made up to $250 \mathrm{ml}$. This solution was filtered and kept in a clean bottle and place in a cool place.

\section{Preparation of standard ascorbic acid solution}

Standard ascorbic acid (50 mg) was taken in $50 \mathrm{ml}$ volumetric flask and the volume was made up with oxalic acid solution $(0.4 \%)$. This solution was kept in a cool place for 24 hours before use.

\section{Preparation of oxalic solution}

Oxalic acid (4 g) was taken in a volumetric flask and volume was made up to 1 liter with distilled water.

\section{Standardization of dye}

Standard ascorbic acid solution (5 ml) was taken in a conical flask and was titrated against dye solution till light pink color persisted for 15 seconds.

\section{Dye factor $(\mathrm{f})=\underline{\mathrm{ml} \text { of ascorbic acid solution taken }}$ Volume of dye used}

Dye factor was determined separately for each determination.

Preparation of sample: $10 \mathrm{ml}$ of sample was taken in a volumetric flask and volume was made up to $100 \mathrm{ml}$ with $0.4 \%$ oxalic acid solution.

Titration of sample: Sample solution $(10 \mathrm{ml})$ was taken in a conical flask and titrated against the dye solution till light pink color appeared which persisted for 15 second. Three consecutive readings were taken for each sample. A blank titration was also carried out.

Calculation: Ascorbic acid content was calculated by using the following formula

Ascorbic acid $(\mathrm{mg} / 100 \mathrm{~g})=\underline{\mathrm{L} \times \mathrm{F} \times 100 \times 100}$

$$
\mathrm{D} \times \mathrm{P}
$$

$\mathrm{L}=$ Volume of dye $(\mathrm{ml})$ used.

$\mathrm{F}=$ dye factor.

$\mathrm{D}=\mathrm{Wt}$. $(\mathrm{g})$ of jam taken for dilution.

$\mathrm{P}=$ Volume $(\mathrm{ml})$ of sample taken for titration.

\section{Total sugar}

Reducing and non-reducing sugar was determined by lane Eynon method as reported in AOAC (2000).

\section{Reducing sugars}

Reagents: Fehling -A: Dissolved $34.65 \mathrm{~g}$ of $\mathrm{CuSo}_{4} .5 \mathrm{H}_{2} \mathrm{O}$ in $500 \mathrm{ml}$ distilled water.

Fehling-B: Dissolved $173 \mathrm{~g}$ sodium potassium tartrate and $50 \mathrm{~g}$ of $\mathrm{NaOH}$ in $500 \mathrm{ml}$ distilled water.

\section{Indicator: Methyl blue}

Procedure: 2 gram of jam was taken and dissolved in distilled water and volume was made up to $100 \mathrm{ml}$ with distilled water. The burette was filled with this solution. $5 \mathrm{ml}$ of Fehling A and $5 \mathrm{ml}$ of Fehling B solution along with $10 \mathrm{ml}$ of distilled water was taken in a conical flask. The flask was heated till boiling without disturbing the flask. Diluted jam solution was added from the burette drop by drop while boiling till the color become brick red in the flask. A drop of methylene blue was 
Citation: Kamal T, Khan S, Riaz M, Safdar M (2015) VFunctional Properties and Preparation of Diet Apricot Jam. J Food Process Technol 6: 475. doi:10.4172/2157-7110.1000475

Page 4 of 5

added as indicator in the boiling solution with out shaking the flask. If red color changed to blue for a moment, reduction was complete, again titrate till red color persisted

Calculations : $5 \mathrm{ml}$ of Fehling A $+5 \mathrm{ml}$ of Fehling B will reduce, $0.05 \mathrm{~g}$ of reducing sugar.

$5 \mathrm{ml}$ of Fehling A $+5 \mathrm{ml}$ of Fehling B $=\mathrm{X} \mathrm{ml}$ of $2 \%$ sodium $=0.05$ $\mathrm{g}$ of reducing sugar.

$100 \mathrm{ml}$ of $2 \%$ solution will contain

$\underline{0.05 \times 100}=\mathrm{Y} \mathrm{g}$ of reducing sugar.

$\mathrm{X} \mathrm{ml}$

$\%$ Reducing sugar in solution $=\underline{\mathrm{Y} \times 100}$ 2

\section{Non reducing sugars}

Procedure: 2 gram of jam sample was taken and dissolved in distilled water and volume was made up to $100 \mathrm{ml}$ from this solution $20 \mathrm{ml}$ was taken in a flask and $10 \mathrm{ml}$ of N HCL solution was added and heated in a boiling water bath for $30 \mathrm{~min}$. Then on cooling 10 $\mathrm{ml}$ of $1 \mathrm{~N} \mathrm{NaOH}$ solution was added and made the volume up to 250 $\mathrm{ml}$ with distilled water. The burette was filled with the solution. 5 $\mathrm{ml}$ of Fehling A and $5 \mathrm{ml}$ of Fehling B solutions along with $10 \mathrm{ml}$ of distilled water was taken in a conical flask and boiled. On boiling it was titrated against the sample solution from the burette till color changed to brick red. It was tested with Methylene blue as indicator till red brick color persisted.

Calculations : $\mathrm{X} \mathrm{ml}$ of sample solution contain $=0.05 \mathrm{~g}$ of reducing sugar.

$250 \mathrm{ml}$ of jam solution contain $=\underline{250 \times 0.05}=\mathrm{Y}$ g of reducing sugar. $\mathrm{X} \mathrm{ml}$

$250 \mathrm{ml}$ of solution was prepared from $20 \mathrm{ml}$ of original $2 \%$ solution.

So $20 \mathrm{ml}$ of $2 \%$ solution contain $\mathrm{Y} \mathrm{g}$ of reducing sugar.

$100 \mathrm{ml}$ of $2 \%$ solution contain $=\underline{\mathrm{Y} \mathrm{x} 100}=\mathrm{P} \mathrm{g}$ of reducing sugar.

This $100 \mathrm{ml}$ was prepared from $2 \mathrm{~g}$ of sample.

$10 \mathrm{ml}$ of sample contain $\mathrm{P} \mathrm{g}$ of reducing sugar.

$100 \mathrm{ml}$ of solution contain $=\underline{\mathrm{P} \times 100}=\mathrm{Q} \mathrm{g}$ of reducing sugar.

$\mathrm{Q}$ g of reducing sugar $=$ inverted sugar + Free reducing sugar.

Non reducing sugar $=$ Total reducing sugar - free reducing sugar.

\section{Results and Discussion}

Apricots were collected from the market and brought to the PCSIR, Laboratories Complex, and Peshawar. Then apricots transferred to the Food Science Section. Apricot diet jam was prepared with the addition of non nutritive sweeteners (aspartame and saccharin)

The samples were analyzed for $\mathrm{PH}$, vit. C, moisture, acidity, reducing sugars, non reducing sugars and TSS.

The data shown in the table represents in triplicate (Table 1).

\begin{tabular}{|c|c|c|c|c|}
\hline $\begin{array}{c}\text { Table } \\
\text { Parameters }\end{array}$ & R1 & R2 & R3 & Mean \\
\hline pH & 3.70 & 3.69 & 3.68 & 3.69 \\
\hline $\begin{array}{c}\text { Vit. C } \\
\text { (mg/100g)\% }\end{array}$ & 6.60 & 6.54 & 6.49 & 6.54 \\
\hline Moisture (\%) & 78.00 & 77.04 & 76.01 & 77.01 \\
\hline $\begin{array}{c}\text { Titratable } \\
\text { acidity (\%) }\end{array}$ & 0.64 & 0.66 & 0.68 & 0.66 \\
\hline $\begin{array}{c}\text { Reducing } \\
\text { sugars (\%) }\end{array}$ & 4.0 & 4.1 & 4.3 & 4.13 \\
\hline $\begin{array}{c}\text { Non-reducing } \\
\text { sugars (\%) }\end{array}$ & 9.5 & 9.2 & 9.0 & 9.2 \\
\hline \begin{tabular}{c} 
TSS (brix) \\
\hline
\end{tabular} & 21.1 & 21.3 & 21.7 & 21.3 \\
\hline
\end{tabular}

Table 1:The data shown in the table represents in triplicate.

\section{pH}

Result regarding $\mathrm{pH}$ of jam showed that it contained 3.70, 3.69 and 3.68. The mean value was recorded as 3.69. The maximum increase was recorded as 3.70 and minimum increase was recorded as 3.68 . The results are in agreement with Anjum [16], who observed decreased in $\mathrm{pH}$ of dried apricot diet jam.

\section{Ascorbic acid}

Result regarding ascorbic acid of jam showed that it contained $6.60 \%, 6.54 \%$ and $6.49 \%$. The mean value was recorded as $6.54 \%$. The maximum increase was recorded as $6.60 \%$ and minimum increase was recorded as $6.49 \%$. The results are in agreement with Anjum et al. who observed decreased in ascorbic acid content of dried apricot diet jam.

\section{Moisture (\%)}

Result moisture of jam showed that it contained $78.00 \%, 77.04 \%$ and $76.01 \%$. The mean value was recorded as $77.01 \%$. The maximum increase was recorded as $78.00 \%$ and minimum increase was recorded as $76.01 \%$. The results are in agreement with Anjum [16] who observed decreased in $\%$ moisture of dried apricot diet jam.

\section{Total soluble solids}

Result regarding total Soluble Solids of jam showed that it contained $21.1 \%, 21.3 \%$ and $21.7 \%$. The mean value was recorded as $21.3 \%$. The maximum increase was recorded as $21.7 \%$ and minimum increase was recorded as $21.1 \%$. The results are in agreement with Anjum [16] who studied that there was an increased in TSS of dried apricot diet jam.

\section{Reducing sugars}

Result regarding reducing sugars of jam showed that it contained $4.0 \%, 4.1 \%$ and $4.3 \%$. The mean value was recorded as $4.13 \%$. The maximum increase was recorded as $4.3 \%$ and minimum increase was recorded as $4.0 \%$. The results are in agreement with) Anjum [16], who observed increased in reducing sugars of dried apricot diet jam.

\section{Non reducing sugars}

Results regarding non reducing sugars of jam showed that it contained $9.5 \%, 9.2 \%$ and $9.0 \%$. The mean value was recorded as $9.2 \%$. The maximum increase was recorded as $9.5 \%$ and minimum increase was recorded as 9.0. The results are in agreement with Anjum [16], who 
Citation: Kamal T, Khan S, Riaz M, Safdar M (2015) VFunctional Properties and Preparation of Diet Apricot Jam. J Food Process Technol 6: 475. doi:10.4172/2157-7110.1000475

Page 5 of 5

observed decreased in non Reducing sugars of dried apricot diet jam.

\section{Titratable acidity $(\%)$}

Result regarding titratable acidity (\%) of jam showed that it contained $0.64 \%, 0.66 \%$ and $0.68 \%$. The mean value was recorded as $0.66 \%$. The maximum increase was recorded as $0.68 \%$ and minimum increase was recorded as $0.64 \%$. The results are in agreement with Anjum [16], who observed increased in\% acidity of dried apricot diet jam [17].

\section{Conclusion}

It is concluded from this study that new product such as apricot diet jam can be prepared. The product has longer shelf life then fresh fruit and is easy to serve, utilize minimum place for storing.

\section{Recommendations}

1. The same work should be carried out on other fruit jam.

2. This research work was carried out at room temperature. So further research work should be carried out in control storage condition.

3. Further research should be carried out to estimated calories of diet apple jam.

4. The further research should be carried out to determine microbial count during storage intervals.

5. Nutritive value of the apricot jam may be evaluated by using them on the patients to see the efficiency of the product whether it is perfect diet product or not.

\section{References}

1. Agric. Stat. of Pak (2008-2009) Government of Pakistan. Ministry of Food, Agriculture and Livestock, Economic wing. Islamabad.

2. Wills RH (1987) Composition of Australian fresh fruit and vegetables. Food Tech. Aust 39: 523-526.

3. Canellas J, Femenia A, Rosello C, Soler L (1992) Chemical composition of the shell of apricot seed. $\mathrm{J}$ of the Sci of Food and Agric 59: 269-271.
4. FDA (1985) Guide lines for Low Caloric Food for Diabetic and Dietetic Purpose, USA.

5. Anderson G (1997) Sugars and health: a review. Res 17: 1485-1498.

6. Lop SCF, Silva RSF, Beleia AP (1999) Formulation and evaluation of dry dessert mix containing sweetener combinations using mixture response methodology. Food Chem 66: 167-171.

7. Sheryl A, Hutchinsona, Gregory S, Chi-Tang H (1999) Stability and degradation of the high intensity sweeteners: Aspartame, alitame and sucralose. Food Rev. Int 15: 249-261.

8. Mohammad AM, Peerzada RH, Safi F, Abdul RH (2009) Effect of sulphitting and drying methods on physicochemical and sensorial quality of dried apricots during ambient storage. Int $\mathrm{J}$ of Food Sci and Tech 44: 1157-1166.

9. Zhu Y, Guo Y, Ye M, James FS (2005) Separation and simultaneous determination of four artificial sweeteners in food and beverages by ion chromatography. J Chromatogr A 1085: 143-146.

10. Henkel J, Reitz DO (2003) Aspartame. National Parkinson's Foundation.

11. Malik A, Jeyarani T, Raghavai B (2002) A comparison of artificial sweeteners stability in lime lemon flavored carbonated beverages. J Food Qual 25: 75-82.

12. Laimer Da Câmara Machado M, Paltrinieri S, Hanzer V, Arthofer W, Strommer $S$, et al. (2001) Presence of European stone fruit yellows (ESFY or $16 \mathrm{SrX}-\mathrm{B}$ ) phytoplasmas in apricots in Austria. Plant Pathology 50: 130-135.

13. Awan J, Salim UR (1999) Food Preservation manual Uni-Tech. Comp. Faisalabad.

14. Alizai MN, Zulfiqar A (1997) Cooperative investigation of sun drying of apricots and their products in NWFP and Northern areas of Pakistan. Sarhad of Agric 13: $501-509$.

15. Arlington VA (2000) Official methods of analysis. The Association of Analytical chemists. $17^{\text {th }}$ (Edn.) Washington, USA.

16. Anjum FM, Maqdam-ud-din I, Pasha AR (2000) Preparation and evaluation of dried diet apricot jam.

17. Fethi K, Fikret K (2009) Effects of sulphurisation on vitamins (A, C and E) and malondialdehyde in apricots. Int $\mathrm{J}$ of Food Sci and Tech 44: 987-993. 